\title{
Water volume reduction increases eutrophication risk in tropical semi-arid reservoirs
}

\author{
A redução do volume intensifica o risco a eutrofização em reservatórios do \\ semiárido tropical
}

Carlos Alberto Nascimento da Rocha Junior ${ }^{1 *}$, Mariana Rodrigues Amaral da Costa ${ }^{2}$, Rosemberg Fernandes Menezes ${ }^{3}$, José Luiz Attayde ${ }^{2}$ and Vanessa Becker ${ }^{1,2}$

'Programa de Pós-graduação em Engenharia Sanitária, Departamento de Engenharia Civil, Universidade Federal do Rio Grande do Norte - UFRN, Av. Senador Salgado Filho, 3000, Campus Universitário, CEP 59078-970, Natal, RN, Brasil

${ }^{2}$ Programa de Pós-graduação em Ecologia, Universidade Federal do Rio Grande do Norte - UFRN, Av. Senador Salgado Filho, 3000, Campus Universitário, CEP 59078-970, Natal, RN, Brasil

${ }^{3}$ Programa de Pós-graduação em Biodiversidade, Centro de Ciências Agrárias, Universidade Federal da Paraíba - UFPB, Rodovia PB-079, Km 12, Campus II, CEP 58397-000, Areia, PB, Brasil *e-mail: rochajunior.can@gmail.com

Cite as: Rocha Junior, C.A.N. et al. Water volume reduction increases eutrophication risk in tropical semi-arid reservoirs. Acta Limnologica Brasiliensia, 2018, vol. 30, e106.

Abstract: Aim: Global patterns of temperature and precipitation have significantly changed over the last century and nearly all predictions point to even greater changes by the end of 2100 . Long periods of drought in semi-arid regions generally reduce reservoirs and lakes water level, increasing the nutrients concentrations in the water. Our principal hypothesis is that water volume reduction, driven by prolonged droughts, will increase reservoirs susceptibility to eutrophication and accordingly an increase in trophic state. To test this hypothesis, we used a comparative analysis of ecosystems in a space-for-time substitution approach, in a Brazilian semi-arid region, to predict the consequences of reservoirs water volume reduction on key limnological variables. Methods: We sampled 16 reservoirs located in two sub-basins with contrasting rainfall regimes, inserted on Piranhas-Açu watershed. The Serido River basin (SB) is dry and the Piancó River basin (SB) is humid, with annual mean precipitation of 500 and $700 \mathrm{~mm}$, respectively. Linear regressions analyzes were performed to assess whether the percentage of maximum volume stored (\%MVS) is a good predictor for total phosphorus (TP), total nitrogen (TN) and chlorophyll-a (CHLA). In addition, a two factorial analysis of variance (two-way ANOVA) was performed to test for period (dry, very dry and extremely dry), basin ( $\mathrm{SB}$ and $\mathrm{PB}$ ) and their interactions effects on TP, TN, CHLA, conductivity, turbidity, and Secchi depth. Results: The results showed a reduction in the reservoirs \%MVS both for PB and SB regions. At the extremely dry period, all reservoirs were classified as eutrophic, but TP concentrations reached much higher values in SB than in PB. The linear regressions analyses showed that the TP and TN were negatively related to \%MVS during all periods sampled. The two-way ANOVA showed that there were significant basin and period effects on TP, TN, Secchi depth and turbidity, whereas for CHLA and conductivity only basin effects were observed. In addition, we found significant interaction effects between period and basin on TP, TN and turbidity. Conclusions: We conclude that the contrasting levels of rainfall observed between the two basins affect the water quality and trophic state of the reservoirs and these effects are magnified by water volume reduction. Therefore, our findings might help to predict the consequences of rainfall reductions on freshwater ecosystems of Brazilian drylands.

Keywords: drought; climate change; phosphorous; water shortage; water quality. 
Resumo: Objetivo: Os padróes globais de temperatura e precipitação mudaram significativamente ao longo do último século e quase todas as previsóes apontam para mudanças ainda maiores até o final de 2100. Longos períodos de seca em regióes semiáridas geralmente reduzem o nível de água dos reservatórios e dos lagos, aumentando as concentraçóes de nutrientes na água. Nossa principal hipótese é que a redução do volume de água, impulsionada por secas prolongadas, aumentará a susceptibilidade dos reservatórios à eutrofização e, portanto, um aumento no estado trófico. Para testar esta hipótese, utilizamos uma abordagem comparativa utilizando o espaço em substituição ao tempo para prever as consequências da redução do volume de água dos reservatórios de uma região do semiárido brasileiro sobre variáveis limnológicas chave. Métodos: Foram estudados 16 reservatórios em duas sub-bacias, com regimes de precipitação contrastantes, inseridos na bacia Piranhas-Açu. A bacia do Piancó (PB) e a bacia do Seridó (SB) são consideradas seca e úmida, respectivamente. Análises de regressóes lineares foram realizadas para avaliar se a porcentagem de volume máximo armazenado (\%MVS) é um bom preditor para estimar as concentraçóes de fósforo total (TP), nitrogênio total (TN) e clorofila-a (CHLA). Além disso, foi realizada uma ANOVA bifatorial para comparar os efeitos da diferença dos períodos (seco, muito seco e extremamente seco), das regióes geográficas (SB e PB) e das interaçóes entre esses fatores sobre TP, TN, CHLA, condutividade, turbidez e profundidade do Secchi. Resultados: Os resultados mostraram uma reduçáo de \%MVS nos reservatórios tanto em SB quanto em PB. No período definido como extremamente seco, todos os reservatórios foram classificados como eutróficos, mas as concentraçóes de TP atingiram valores muito mais altos em SB do que em PB. As análises de regressóes lineares mostraram que o TP e TN estavam relacionados negativamente com \% MVS durante todos os períodos amostrados. Os resultados da ANOVA bifatorial mostraram que houve efeitos significativos da bacia e do período sobre TN, TP, profundidade Secchi e turbidez, enquanto que para a CHLA e condutividade, apenas os efeitos da bacia foram observados. Além disso, efeitos de interação foram observados entre período e regiáo sobre TP, TN e turbidez. Conclusóes: Conclui-se que as diferenças contrastantes de precipitação pluviométrica entre duas sub-bacias afetam a qualidade da água e o estado trófico dos reservatórios e esses efeitos são potencializados com a redução do volume de água. Portanto, nossas descobertas podem ajudar a prever as consequências das mudanças climáticas nos ecossistemas de água doce do semiárido brasileiro.

Palavras-chave: seca; mudanças climáticas; fósforo; escassez hídrica; qualidade da água.

\section{Introduction}

The global patterns of temperature and precipitation have significantly changed over the last century and nearly all predictions point to even greater changes by the end of 2100 , intensified by the environmental impacts driven by anthropogenic actions (Meehl et al., 2007). Most climate change models have foreseen increased frequency of extreme events, such as intense rainfall and severe drought (IPCC, 2014), which will magnify reservoirs water level fluctuations. According to the Intergovernmental Panel on Climate Change (IPCC), world arid and semi-arid regions are the most susceptible and sensitive to climate changes, because the high variability on rainfall in time and space (IPCC, 2014). For the Brazilian semi-arid region, for instance, climate models predict a temperature increase of about $5{ }^{\circ} \mathrm{C}$ and rainfall reduction of about $50 \%$ at the rainy season, as well as increases in intensity and duration of droughts during the 21st century (Oyama \& Nobre, 2003)

Extreme climate events play a crucial role in regulating nutrients in freshwater ecosystems. Seasonal fluctuations in reservoirs water level are associated with changes in the physical, chemical and biological characteristics of these systems (Arfi, 2003). Intense rainfall may intensify soil erosion and increase the input of phosphorus and nitrogen in water bodies, which is often aggravated by multiple types of land use (e.g. agriculture, livestock and human occupation) (Mooij et al., 2009; Moss et al., 2011). In semiarid regions, the generally observed negative water balance (water loss higher than gain) might be aggravated by prolonged droughts and intense water abstraction, which will inevitably decrease reservoirs and lakes water level and accordingly concentrating nutrients in a smaller volume (Costa et al., 2016) and increasing their susceptibility to eutrophication (Moss et al., 2011).

Eutrophication is a natural or artificial process driven by the enrichment of water by nutrients, mainly phosphorus and nitrogen, which increases primary productivity and eventually favors blooms of cyanobacteria species, with consequent disequilibrium of aquatic ecosystems, progressive degradation of the water bodies (Dodds et al., 2009), and dramatic shifts in reservoirs trophic food webs (Jeppesen et al., 2015).

Significant changes are expected in nutrients cycling with the acceleration of the eutrophication process, compromising the water quality of lakes and reservoirs. The phytoplankton growth, for 
instance, intensifies organic matter degradation leading to oxygen depletion that causes mortality of aquatic organism and affects the visual quality of water (Carpenter et al., 1998; Bouvy et al., 1999; Dokulil \& Teubner, 2000; Gemelgo et al., 2009; Bonilla et al., 2012; Sukenik et al., 2012; Brasil et al., 2016). However, the water level reduction may also increase water turbidity without increasing primary producers, due to augmented resuspension of sediment with inorganic origin that reduces light availability and limits phytoplankton growth (Medeiros et al., 2014; Costa et al., 2016; Jeppesen et al., 2015).

Brazil's semi-arid region is tropical with a highly seasonal rainfall concentration, stable (seasonal) high temperatures and occasionally endures long periods of drought. These factors lead to a high coefficient of variation of annual rivers flow that, combined with the lack of perennial rivers and natural lakes, has led to the need for, and dependence upon, man-made lakes to meet the water requirements of industry, agriculture, and households (Thornton \& Rast, 1993). Moreover, water quality degradation derived from eutrophication affects the multiple social and ecological services provided by freshwater ecosystems, such as recreation, aesthetic value, tourism potential, public water supply, fishing and biodiversity (Barbosa et al., 2012; Miranda et al., 2014). Since lakes and reservoirs provide essential freshwater ecosystem services, studies about reservoir's trophic states in regions severely affected or threatened by prolonged drought events are useful to hone the current management policies of water use in semiarid regions.
Even though there are multiple studies in the Brazilian semi-arid region dealing with eutrophication and their associated problems in lakes and reservoirs (Freire et al., 2009; Barbosa et al., 2012; Medeiros et al., 2014; Costa et al., 2016; Brasil et al., 2016), few have analyzed how dramatic shifts in rainfall reduction affect key limnological variables, such us total phosphorus and chlorophyll-a. Thus, this study aims to test the hypothesis that the reduction of water volume, driven by prolonged droughts, affects the trophic state of Brazilian semi-arid reservoirs by increasing their susceptibility to eutrophication. To do so, we used a comparative analysis of ecosystems in a space-for-time substitution approach to predict the consequences of reservoirs water volume reduction on the total concentrations of phosphorus, nitrogen and chlorophyll-a, turbidity, conductivity, and Secchi depth. We compared the previous variables from two sets of reservoirs located in a Brazilian semi-arid region with contrasting levels of precipitation.

\section{Material and Methods}

We studied 16 reservoirs (Table 1 ) belonging to the Piranhas-Açu River watershed $\left(04^{\circ}-08^{\circ} \mathrm{S}\right.$ and $36^{\circ}-39^{\circ} \mathrm{W}$ ), which are totally inserted in the semi-arid region (in the Caatinga biome) of Northeastern Brazil. The Piancó (PB) and Seridó sub-basins (SB) are inserted, respectively, upstream and downstream of the Piranhas-Açu River watershed (Figure 1). The two sub-basins are characterized by having contrasting precipitation regimes: $\mathrm{PB}$ is humid with annual precipitation around $700 \mathrm{~mm}$, whereas SB

Table 1. Morphometric variables for the 16 reservoirs included in the analyses.

\begin{tabular}{lcccc}
\hline \multicolumn{1}{c}{ Reservoirs } & Sub-basins & $\begin{array}{c}\text { Maximum capacity } \\
\text { storage } \mathbf{( m}^{\mathbf{3}} \mathbf{n}\end{array}$ & Area (ha) & $\begin{array}{c}\text { Average depth } \\
\text { near the dam } \mathbf{( m )}\end{array}$ \\
\hline Condado & Piancó basin & $35,016.000$ & 441.00 & 14.7 \\
Serra Vermelha I & Piancó basin & $11,801.173$ & 155.21 & 8.0 \\
Piranhas & Piancó basin & $25,696.200$ & 234.2 & 16.0 \\
Vazante & Piancó basin & $9,091.200$ & 133.76 & 16.0 \\
Bruscas & Piancó basin & $38,206.463$ & 306.26 & 15.0 \\
Saco & Piancó basin & $97,488.089$ & 640.78 & 21.0 \\
Cachoeira dos Alves & Piancó basin & $10,611.196$ & 208.81 & 3.8 \\
Jenipapeiro (Buiú) & Piancó basin & $70,757.250$ & 692.65 & 18.0 \\
Gargalheiras & Seridó basin & $44,421.480$ & 780.00 & 11.0 \\
Cruzeta & Seridó basin & $23,545.745$ & 616.00 & 1.5 \\
Itans & Seridó basin & $81,750.000$ & 1340.00 & 5.5 \\
Carnaúba & Seridó basin & $25,710.900$ & 506.50 & 3.0 \\
Passagem das Traíras & Seridó basin & $49,702.394$ & 1004.82 & 5.0 \\
Esguicho (Divino Espírito Santo) & Seridó basin & $27,937.310$ & 430.18 & 4.7 \\
Caldeirão de Parelhas & Seridó basin & $9,320.657$ & 183.78 & 2.2 \\
Boqueirão de Parelhas & Seridó basin & $84,792.119$ & 1267.27 & 7.5 \\
\hline
\end{tabular}




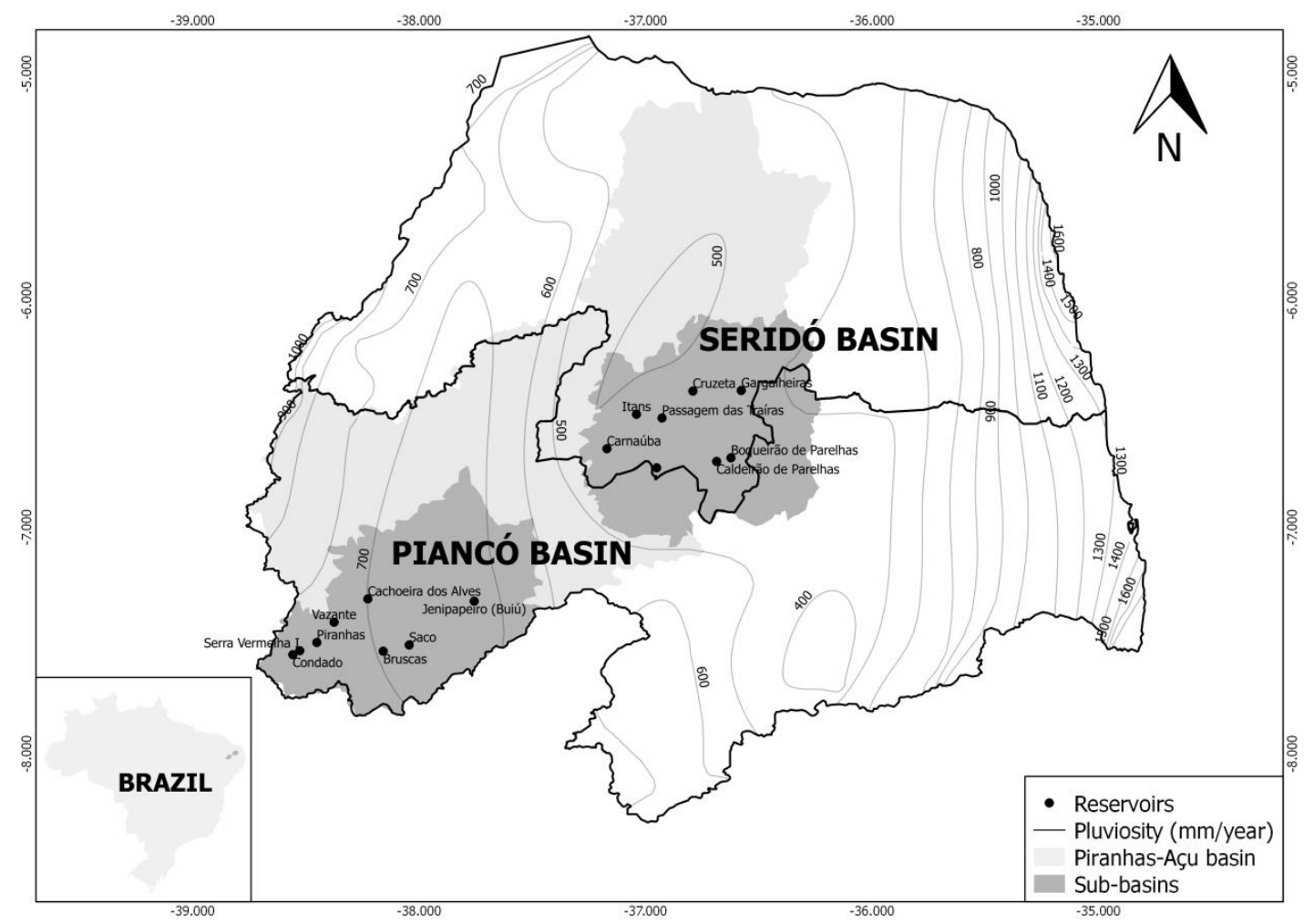

Figure 1. Map of Brazil highlighting the Piancó (PB) and Seridó (SB) basins inserted in the Piranhas-Açu River watershed. The lines connecting places that receive equal amounts of rainfall (isohyets), show the differences in mean annual rainfall (MAR) between the regions. Both sets of reservoirs are located in the semi-arid, but in the SB the $\mathrm{MAR}$ is around $500 \mathrm{~mm} /$ year, whereas in the $\mathrm{PB}$ the MAR is around $700 \mathrm{~mm} /$ year.

is dry with annual precipitation around $500 \mathrm{~mm}$ (ANA, 2010). The regional climate is tropical semi-arid (BS'h'; Kottek et al., 2006; Alvares et al., 2013), characterized by having negative water balance most of the year and rainy season occurring between January and May (AESA and SEMARH).

The sampling periods were categorized as $d r y$ (Jun/2014), very dry (Jan/2014) and extremely dry (Jan/2016). These periods were defined according to the accumulated rainfall in each season sampled compared to the historical average. All information were based on the monitoring rainfall data collected by the Agricultural Research Company of Rio Grande do Norte state (EMPARN) and the Water Management Executive Agency (AESA) of Paraíba state. The study was carried out during an event of prolonged drought in the Brazilian semi-arid region.

Integrated water samples were collected from the water column using a PVC tube at five sites on the deepest point of each reservoir (near the dam) in the three sampling campaigns. Subsamples from the integrated water samples were used for estimating total concentrations of phosphorus, nitrogen and chlorophyll-a. Chlorophyll-a (CHLA) was extracted from the fiber filters (GF/C Whatman) with $95 \%$ ethanol and absorbance was measured at 665 and $750 \mathrm{~nm}$ (Jespersen \& Christoffersen, 1987). Turbidity and conductivity were measured each meter from the surface to the bottom, using multiparameter probe Horiba (U-22 model, Kioto, Japan). Water transparency was measured through the Secchi disk. The concentrations of total phosphorus were analyzed by the ascorbic acid colorimetric method, after oxidation with potassium persulfate (Valderrama, 1981). Total nitrogen (TN) was analyzed by the combustion of water samples using a carbon analyzer TOC-V Shimadzu with a TN analyzer attached.

The morphometric variables and the percent of maximum volume stored (\%MVS) and their variations in the reservoirs throughout the study period were provided by the Water Management Executive Agency of Paraíba state (AESA) and the State Secretariat for the Environment and Water Resources of Rio Grande do Norte state (SEMARH).

We classified the reservoirs trophic state according to Thornton \& Rast (1993). Reservoirs 
with total phosphorus (TP) concentrations lower than $50 \mu \mathrm{g} / \mathrm{L}$ and total chlorophyll-a (CHLA) lower than $15 \mu \mathrm{g} / \mathrm{L}$ were considered mesotrophic, whereas those with TP higher than $50 \mu \mathrm{g} / \mathrm{L}$ and CHLA higher than $15 \mu \mathrm{g} / \mathrm{L}$ were considered eutrophic.

A two-way ANOVA was performed to test the isolated and combined effects of the region and the sampling periods on TP, TN, CHLA, conductivity, turbidity, and Secchi depth. In addition, A simple linear regression was done to assess if the $\%$ MVS were related to the response variables TP, TN, and CHLA. Prior to performing the analysis, all variables were $\log$ transformed $(\log x+1)$ to improve normality. A Shapiro-Wilk test was performed to check for data normality.

\section{Results}

In all three periods, the reservoirs in the Seridó basin had lower percentage of maximum volume storage than reservoirs in the Piancó basin (Figure 2). For PB, the median \%MVS was approximately $40 \%$ in the first and second sampling period, but a drastic decrease was observed at the last period with most of the reservoirs reaching less than $20 \%$ of MVS (Figure 2). For SB, the median $\%$ MVS was nearly $15 \%$ in the $d r y$ and very $d r y$ sampling periods and decreased to almost $0 \%$ at the last period (Figure 2).

Conversely, in all three periods the reservoirs in the Seridó basin had higher concentrations of total phosphorus (Figure 3A) and chlorophyll-a (Figure 3C), and conductivity (Figure 3D) than in the Piancó basin. For the first two periods, the values of TN (Figure 3B), turbidity (Figure 3E)

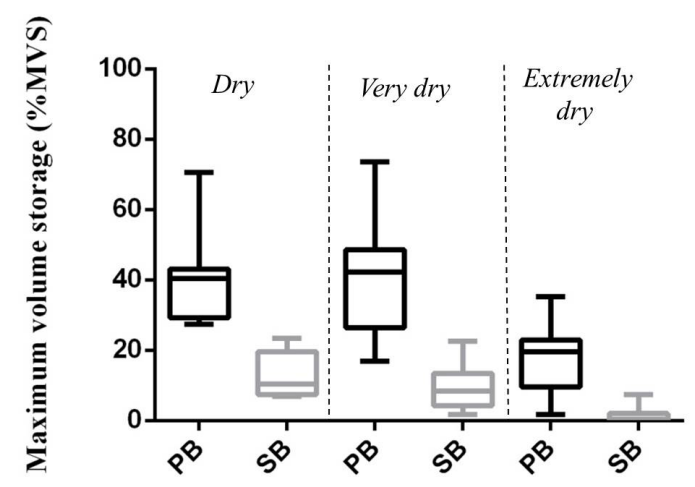

Figure 2. Variation of the percent of maximum volume stored (\%MVS) in the reservoirs during the dry, very dry and extremely dry seasons. Bands inside the boxplots represent their medians and vertical bars represent minimum and maximum values. PB - Piancó basin; $\mathrm{SB}$ - Seridó basin. and Secchi depth (Figure 3F) did not show any difference between the regions, however, in the last period there was an increase of TN and turbidity and a reduction of Secchi depth in SB in relation to PB. Based on TP concentrations, the trophic state of $\mathrm{PB}$ reservoirs varied between mesotrophic and eutrophic, whereas SB reservoirs were all classified as eutrophic (Figure 3A). At the last period, all reservoirs in both regions were classified as eutrophic, but TP concentrations reached much higher values in SB than in PB (Figure 3A). Based on CHLA concentrations, the great majority of the reservoirs were considered eutrophic at the $d r y$ and very dry periods (Figure 3C). At the last sampling period (extremely dry), some reservoirs of $\mathrm{PB}$ moved from eutrophic to mesotrophic state, while in all SB reservoirs CHLA concentrations had the highest values (Figure $3 \mathrm{C}$ ).

The two-way ANOVA results (Figure 3) showed that both region and period affected TP, TN, turbidity and Secchi, but CHLA was only affected by region and conductivity was only affected by period. Interaction effects between region and season were found only for TP, TN and turbidity.

The linear regressions analyses showed that the TP and TN were negatively related to \%MVS during all sampling periods, especially in the extremely dry period for TP, where the coefficient of determination $\left(\mathrm{R}^{2}\right)$ were higher (Figure $4 \mathrm{~A}$ and Figure 4B). However, significant relationship between CHLA and \%MVS was only found at the very dry and extremely dry periods (Figure 4C).

\section{Discussion}

This study describes the intensification of eutrophication due to reduction in water volume storage caused by prolonged drought in two semi-arid regions with contrasting rainfall regimes. We confirm our hypothesis that water level reduction affects the reservoirs trophic state enhancing the risk of eutrophication. The natural differences in the precipitation levels between the two regions added to their distinct initial conditions, led to an aggravation of reservoir's trophic state. Reservoirs located in the Seridó Basin (SB) were more susceptible to drought effects than those in the Piancó Basin (PB), mainly because it is located in the driest region.

In Northeastern Brazil, seasonal variations in reservoirs water volume are generally followed by nutrients and chlorophyll- $a$ concentrations increase, especially during drought periods (Miranda et al., 2014; Brasil et al., 2016). In our study, we 
(A)

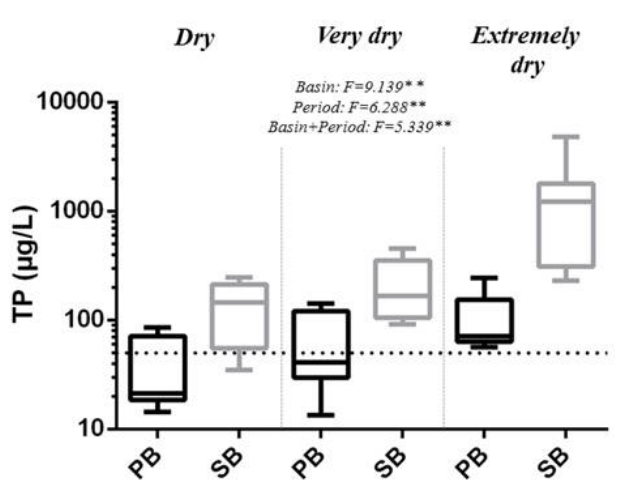

(C)

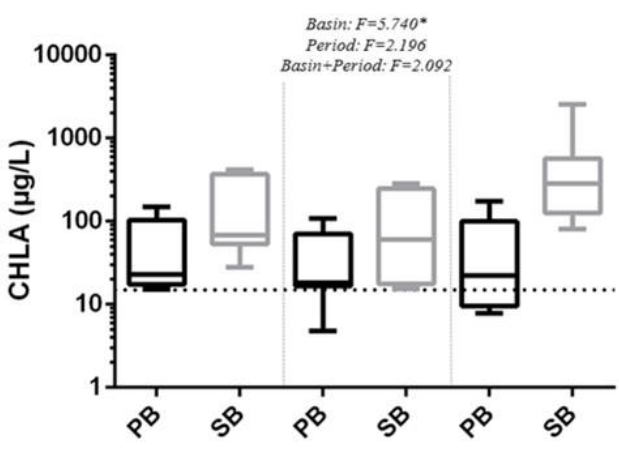

(E)

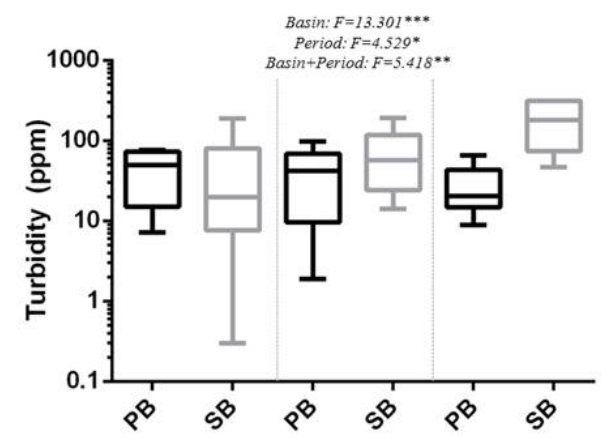

(B)

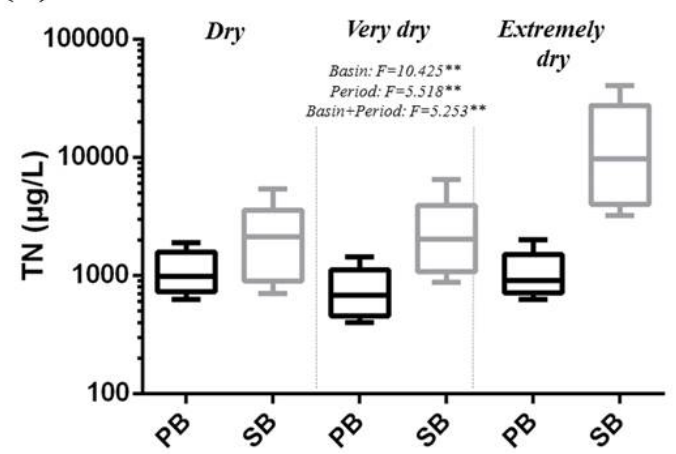

(D)

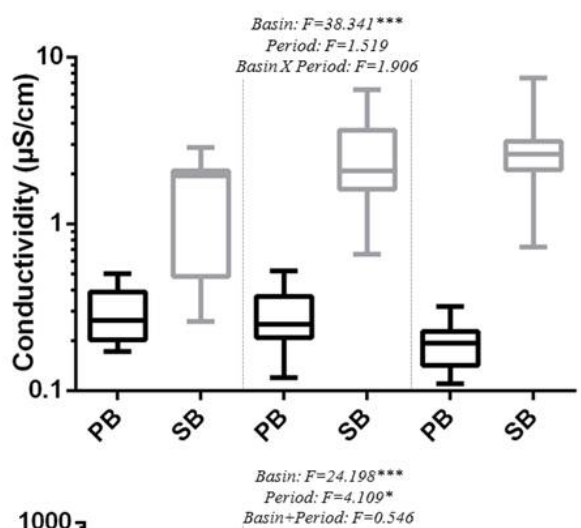

(F)

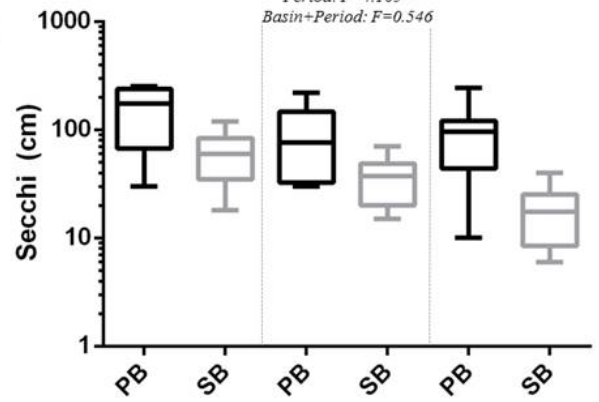

Figure 3. Results of two-way ANOVA for testing the periods (dry, very dry and extremely dry), basins (PB and SB) and their interaction effects on total phosphorus (A), total nitrogen (B), chlorophyll-a (C), conductivity (D), turbidity (E) and Secchi depth (F). The trophic level classification (Mesotrophic $-\mathrm{TP}<50 \mu \mathrm{g} / \mathrm{L}, \mathrm{CHLA}<15 \mu \mathrm{g} / \mathrm{L}$; Eutrophic $-\mathrm{TP}>50 \mu \mathrm{g} / \mathrm{L}, \mathrm{CHLA}>15 \mu \mathrm{g} / \mathrm{L}$ ) was based on Thornton \& Rast (1993). The y-axes are in logarithmic scale. Bands inside the boxplots represent their medians and vertical bars represent minimum and maximum values. $\mathrm{PB}-$ Piancó basin; SB - Seridó basin. The asterisks symbols denote: ${ }^{*} \mathrm{p} \leq 0.05,{ }^{* *} \mathrm{p} \leq 0.01$ and ${ }^{* * *} \mathrm{p} \leq 0.001$.

observed regional and seasonal differences in the percentage of water volume storage along the three samplings periods (dry, very dry and extremely $d r y)$. The high water evaporation rates in the regions (PB and $\mathrm{SB}$ ) combined with the lack of precipitation (i.e. prolonged drought) and reservoirs water abstraction were probably the main drivers of change on water volume along the periods.

The Piancó basin is naturally more humid than the Seridó basin (ANA, 2014) and, therefore, the evaporation rates in this region are smaller compared to SB, which may explain the differences observed in the percentage of accumulated water of the reservoirs between the regions. In the extremely dry period, both groups of reservoirs underwent great water losses, leading some to reach nearly zero percent of water volume storage in SB.

Total phosphorus is considered an important factor for predicting phytoplankton biomass and water quality in lakes and reservoirs of tropical and subtropical regions (Attayde \& Bozelli, 1998; Huszar et al., 2006). Based on TP, most of the reservoirs in our study were considered eutrophic (> $50 \mu \mathrm{g} / \mathrm{L}$ ) (Thornton \& Rast, 1993), but in PB some reservoirs were mesotrophic during the $d r y$ and very dry period. This can be explained by the 
(A)

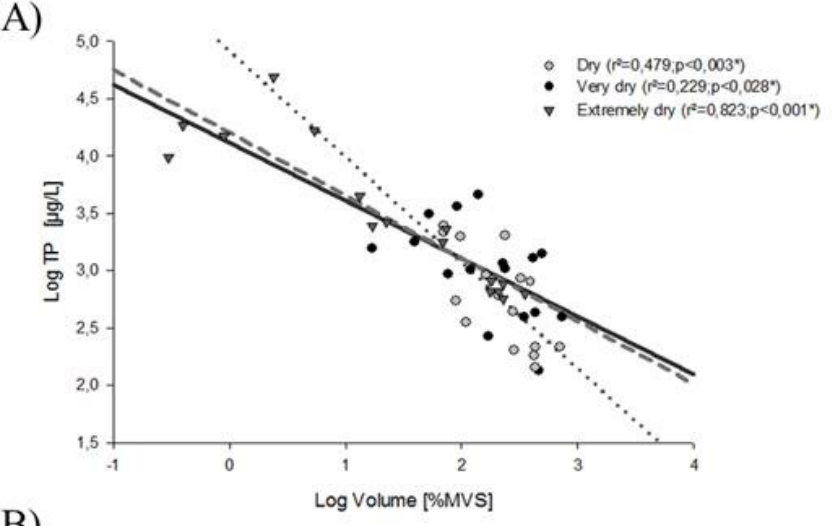

(B)
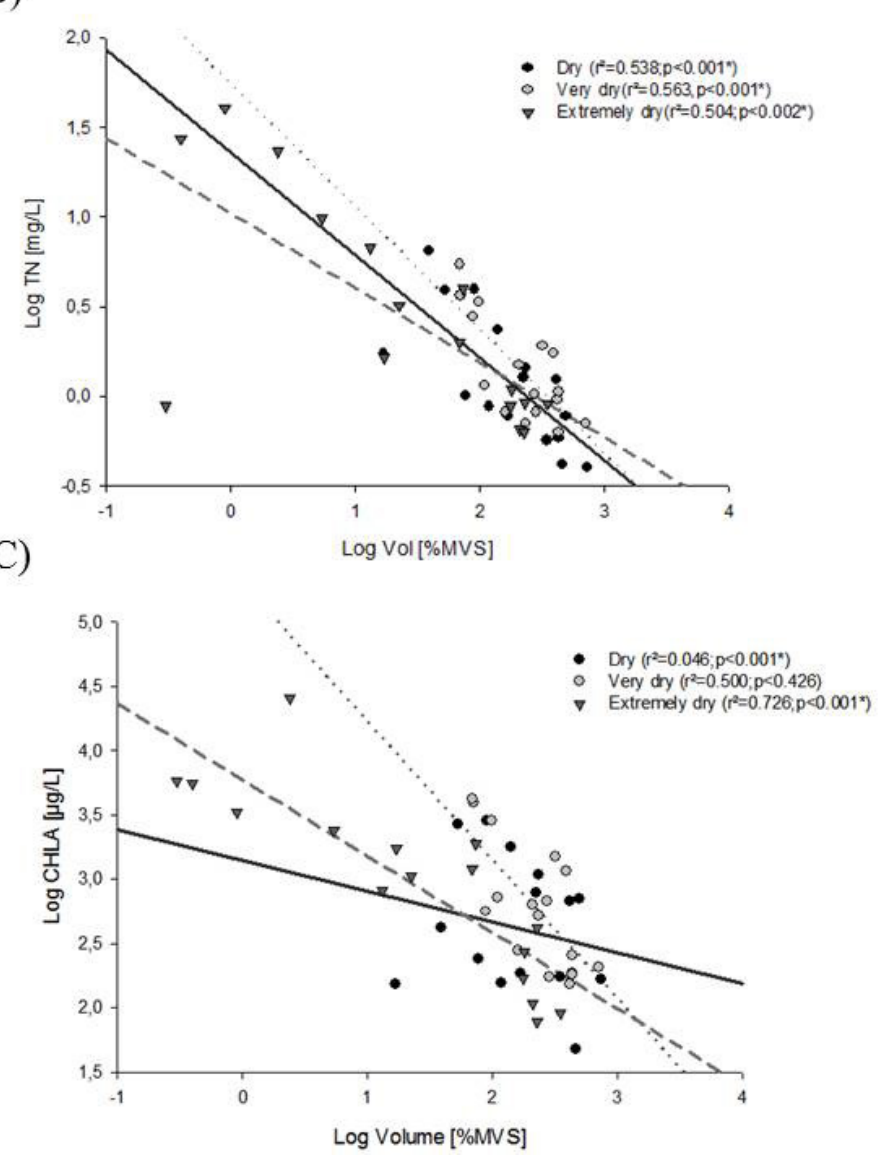

Figure 4. Simple linear regressions relating the percentage of maximum water volume storage (\% MVS) and the total concentrations of total phosphorus (A), total nitrogen (B) and chlorophyll-a (C). The continuous, dashed and pointed lines represent the dry, very dry and extremely dry periods, respectively. The asterisk $\left.{ }^{*}\right)$ denotes that the regression model was significant.

differences observed in the percentage of water volume stored (\%MVS) between regions. However, between the $d r y$ and very $d r y$ periods, $\mathrm{PB}$ reservoirs showed little variability in \%MVS due to the registered rainfall in the $d r y$ period.

Prolonged drought events and accordingly decrease in lakes and reservoirs water volume can magnify eutrophication and degradation of water quality (Bouvy et al., 1999; Jeppesen et al., 2015; Brasil et al., 2016). Similarly in our study, reservoirs from SB responded to water volume reduction with increasing total concentrations phosphorus, nitrogen and chlorophyll-a, turbidity and conductivity, and decreasing water transparency (Figure 3). The same patterns were observed for $\mathrm{PB}$ reservoirs, but the changes were not so marked 
(Figure 3). Furthermore, interaction effects between period and basin (region) were found for TP, TN and turbidity. This may be explained by the natural regional differences in humidity observed between the SB (dry) and PB (humid) regions (Figure 1), which magnified the effects of water volume reduction on the nutrients and turbidity.

Recent studies have indicated that the decrease in \%MVS may lead to increased concentrations of nutrients and algal biomass in shallow and deep reservoirs (Bouvy et al., 1999; Jeppesen et al., 2015; Brasil et al., 2016). Our results corroborated with this and showed that TP, TN and CHLA were negatively related to \%MVS irrespective of the sampling period. However, it is important to emphasize that each aquatic ecosystem can respond in a different way to seasonal hydrological events due to their intrinsic morphological and climatological characteristics (Coops et al., 2003). In contrast to the results showed in the present study, Medeiros et al. (2014) and Costa et al. (2016), report a reduction in algal biomass during drought conditions explained by light limitation as a function of sediment resuspension and inorganic turbidity increase.

We conclude that the contrasting differences in humidity observed between the two regions (PB vs. SB) affect the water quality and trophic state of reservoirs, but with marked differences at an extreme drought event. Water volume reduction increases TP, TN and CHLA concentrations in both sets of reservoirs, but eutrophication is magnified with rainfall reduction. Using a comparative approach of ecosystems in a space-for-time substitution, which assumes that temporal and spatial variation are equivalent, our findings might help to predict the consequences of climate changes on freshwater ecosystems of Brazilian drylands.

\section{Acknowledgements}

I would like to thank the field and laboratory teams: Edson Santana, Anízio Souza, Juliana Leroy, Regina Nobre, Pedro Junger, Bruno Wanderley, Lenice Ventura, Bárbara Bezerra, Fabiana Araújo and Isaac Falcão. We thank Iagê Terra and Herika Cavalcante for the help in elaboration of the delimitation map of the Piranhas-Açu watershed. We also thank Jurandir Mendonça for helping with statistical analyses. This work was supported by The Brazilian National Council for Scientific and Technological Development (CNPq) (Processes Numbers: 442484/2014-3/MCTI/CNPq/Universal 14/2014 and 446138/2015-0/MCTI/CNPq/ANA/No23/2015) and Coordination for the Improvement of Higher Educational Personnel (CAPES/PNPD - Project No: 2304/2011).

\section{References}

AGÊNCIA NACIONAL DE ÁGUAS - ANA. Termos de referência para a elaboração do plano de recursos hidricos da bacia do rio Piranhas-Açu. Brasília, 2010.

AGÊNCIA NACIONAL DE ÁGUAS - ANA. Plano de recursos hídricos da bacia do rio Piranhas-Açu. Brasília, 2014.

ALVARES, C.A., STAPE, J.L., SENTELHAS, P.C., GONÇALVES, J.L.M. and SPAROVEK, G. Köppen's climate classification map for Brazil. Meteorologische Zeitschrift, 2013, 22(6), 711-728. http://dx.doi.org/10.1127/0941-2948/2013/0507.

ARFI, R. The effects of climate and hydrology on the trophic status of Sélingué Reservoir, Mali, West Africa. Lakes and Reservoirs: Research and Management, 2003, 8(3-4), 247-257. http://dx.doi. org/10.1111/j.1440-1770.2003.00223.x.

ATTAYDE, J.L. and BOZELLI, R.L. Environmental heterogeneity and predictive models of chlorophyll a in a Brazilian coastal lagoo. Hydrobiologia, 1998, 390(1-3), 129-139. http://dx.doi. org/10.1023/A:1003546810358.

BARBOSA, J.E.L., MEDEIROS, E.S.F., BRASIL, J., CORDEIRO, R.S., CRISPIM, M.C.B. and SILVA, G.H.G. Aquatic systems in semi-arid Brazil: limnology and management. Acta Limnologica Brasiliensia, 2012, 24(1), 103-118. http://dx.doi. org/10.1590/S2179-975X2012005000030.

BONILLA, S.L., AUBRIOT, M.C.S., SOARES, M., GONZÁLEZ-PIANA, A., FABRE, V.L.M., HUSZAR, M., LURLING, D., ANTONIADES, J., PADISÁK, J. and KRUK, C. What drives the distribution of the bloom-forming cyanobacteria Planktothrix agardhii and Cylindrospermopsis raciborskit? Microbial Ecology, 2012, 79(3), 594-607. http://dx.doi.org/10.1111/j.15746941.2011.01242.x.

BOUVY, M., MOLICA, R., OLIVEIRA, S., MARINHO, M. and BEKER, B. Dynamics of a toxic cyanobacterial bloom (Cylindrospermopsis raciborskii) in a shallow reservoir in the semi-arid region of northeast Brazil. Aquatic Microbial Ecology, 1999, 20, 285-297. http://dx.doi.org/10.3354/ ame 020285 .

BRASIL, J., ATTAYDE, J.L., VASCONCELOS, F.R., DANTAS, D.D.F. and HUSZAR, V.L.M. Droughtinduced water-level reduction favors cyanobacteria blooms in tropical shallow lakes. Hydrobiologia, 2016, 770(1), 145-164. http://dx.doi.org/10.1007/ s10750-015-2578-5. 
CARPENTER, S.R., CARACO, D.L., CORRELL, R.W., HOWARTH, R.W., SHARPLEY, A.N. and SMITH, V.H. Nonpoint pollution of surface waters with phosphorus and nitrogen. Ecological Applications, 1998, 8(3), 559-568. http://dx.doi. org/10.1890/1051-0761(1998)008[0559:NPOSW W]2.0.CO;2.

COOPS, H., BEKLIOGLU, M. and CRISMAN, T.L. The role of water-level fluctuations in shallow lake ecosystems: workshop conclusions. Hydrobiologia, 2003, 506-509(1-3), 23-27. http://dx.doi. org/10.1023/B:HYDR.0000008595.14393.77.

COSTA, M.R.A., ATTAYDE, J.L. and BECKER, V. Effects of water level reduction on the dynamics of phytoplankton functional groups in tropical semiarid shallow lakes. Hydrobiologia, 2016, 778(1), 7589. http://dx.doi.org/10.1007/s10750-015-2593-6.

DODDS, W.K., BOUSKA, W.W., EITZMANN, J.L., PILGER, T.J., PITTS, K.L., RILEY, A.J., SCHLOESSER, J.T. and THORNBRUGH, J.D. Eutrophication of U.S. freshwaters: analysis of potential economic damages. Environmental Science \& Technology, 2009, 43(1), 12-19. http://dx.doi. org/10.1021/es801217q. PMid:19209578.

DOKULIL, M.T. and TEUBNER, K. Cyanobacterial dominance in lakes. Hydrobiologia, 2000, 438(1/3), 1-12. http://dx.doi.org/10.1023/A:1004155810302.

FREIRE, R.H.F., CALIJURI, M.C. and SANTAELLA, S.T. Longitudinal patterns and variations in water quality in a reservoir in the semiarid region of NE Brazil: responses to hydrological and climatic changes. Acta Limnologica Brasiliensia, 2009, 21(2), 251-262.

GEMELGO, M.C.P., MUCCI, J.L.N. and NAVASPEREIRA, D. Population dynamics: seasonal variation of phytoplankton functional groups in brazilian reservoirs (Billings and Guarapiranga, São Paulo). Brazilian Journal of Biology = Revista Brasileira de Biologia, 2009, 69(4), 1001-1013. http:// dx.doi.org/10.1590/S1519-69842009000500004. PMid:19967171.

HUSZAR, V.L.M., CARACO, N.F., ROLAND, F. and COLE, J. Nutrient-chlorophyll relationships in tropical- subtropical lakes: do temperate models fit? Biogeochemestry, 2006, 79(1-2), 239-250. http:// dx.doi.org/10.1007/s10533-006-9007-9.

INTERGOVERNMENTAL PANEL ON CLIMATE CHANGE - IPCC. Climate Change 2014: synthesis report. Geneva, 2014.

JEPPESEN, E., BRUCET, S., NASELLI-FLORES, L., PAPASTERGIADOU, E., STEFANIDIS, K., NÓGES, T., NÓGES, P., ATTAYDE, J.L., ZOHARY, T., COPPENS, J., BUCAK, T., MENEZES, R.F., FREITAS, F.R.S., KERNAN, M., SØNDERGAARD, M. and BEKLIOĞLU, M. Ecological impacts of global warming and water abstraction on lakes and reservoirs due to changes in water level and related changes in salinity. Hydrobiologia, 2015, 750(1), 201-227. http://dx.doi. org/10.1007/s10750-014-2169-x.

JESPERSEN, A.M. and CHRISTOFFERSEN, K. Measurements of chlorophyll-a from phytoplankton using ethanol as extraction solvent. Hydrobiologia, 1987, 109, 445-454.

KOTTEK, M., GRIESER, J., BECK, C., RUDOLF, B. and RUBEL, F. World map of the Koppen-Geiger climate classification updated. Meteorologische Zeitschrift, 2006, 15(3), 259-263. http://dx.doi. org/10.1127/0941-2948/2006/0130.

MEDEIROS, L.C., MATTOS, A., LÜRLING, M. and BECKER, V. Is the future blue-green or brown? The effects of extreme events on phytoplankton dynamics in a semi-arid man-made lake. Aquatic Ecology, 2014, 49(3), 294-307.

MEEHL, G.A., STOCKER, T.F., COLLINS, W.D., FRIEDLINGSTEIN, P., GAYE, A.T., GREGORY, J.M., KITOH, A., KNUTTI, R., MURPHY, J.M., NODA, A., RAPER, S.C.B., WATTERSON, I.G., WEAVER A.J., and ZHAO, Z.C. Climate projections. In: S. SOLOMON, D. QIN, M. MANNING, Z. CHEN, M. MARQUIS, K.B. AVERYT, M. TIGNOR and H.L. MILLER, eds. Climate change 2007: the physical science basis: contribution of Working Group I to the Fourth Assessment Report of the Intergovernmental Panel on Climate Change. Cambridge: Cambridge University Press, 2007, pp. 749-844.

MIRANDA, K., MATTOS, A. and BECKER, V. Influência do uso e ocupaçáo de solo na qualidade da água de um reservatório mesotrófico na regiāo semiárida tropical. In: A. MATTOS and K.M.C. MATTOS, eds. Projeto Mevemuc (monitoramento da evaporação e as mudanças climáticas): contribuição para a hidrologia do semiárido. 1. ed. João Pessoa: Moura Ramos Gráfica Editora, 2014, pp. 319-340.

MOOIJ, W.M., DE SENERPONT-DOMIS, L.N. and JANSE, J.H. Linking speciesand ecosystem-level impacts of climate change in lakes with a complex and a minimal model. Ecological Modelling, 2009, 220(21), 3011-3020. http://dx.doi.org/10.1016/j. ecolmodel.2009.02.003.

MOSS, B., KOSTEN, S., MEERHOFF, M., BATTARBEE, R.W., JEPPESEN, E., MAZZEO, N., HAVENS, K., LACEROT, G., LIU, Z., MEESTER, L., PAERL, H. and SCHEFFER, M. Allied attack: climate change and eutrophication. Inland Waters, 2011, 1(2), 101-105. http://dx.doi. org/10.5268/IW-1.2.359.

OYAMA, M.D. and NOBRE, C.A. A new climatevegetation equilibrium state for tropical South America. Geophysical Research Letters, 2003, 30(23), 2199 2203. http://dx.doi.org/10.1029/2003GL018600.

SUKENIK, A., HADAS, O., KAPLAN, A. and QUESADA, A. Invasion of Nostocales (cyanobacteria) 
to subtropical and temperate freshwater lakesphysiological, regional, and global driving forces. Frontiers in Microbiology, 2012, 3, 83. http://dx.doi. org/10.3389/fmicb.2012.00086. PMid:22408640.

THORNTON, J.A. and RAST, W. A test of hypothesis relating to the comparative limnology and assessment of eutrophication in semi-arid man-made lakes. In: M. STRASKRABA, J.G. TUNDISI and A. DUNCAN, eds. Comparative reservoir limnology and water quality management. Dordrecht: Kluwer
Academic Publishers, 1993, pp. 1-24. http://dx.doi. org/10.1007/978-94-017-1096-1_1.

VALDERRAMA, J.C. The simultaneous analysis of total nitrogen and total phosphorus in natural waters. Marine Chemistry, 1981, 10(2), 109-122. http:// dx.doi.org/10.1016/0304-4203(81)90027-X.

Received: 13 February 2017 Accepted: 16 October 2017 